\title{
Study of Strengthening The Performance of West Rinjani Forest Management Unit to Promoting Sustainable Forest Management in West Tenggara Nusa
}

\author{
Andi Chairil Ichsan* \\ Department of Forestry, Faculty of \\ Agriculture \\ University of Mataram \\ Mataram, Indonesia \\ andi.foresta@unram.ac.id \\ M Markum \\ Department of Forestry, Faculty of \\ Agriculture \\ University of Mataram \\ Mataram, Indonesia
}

\author{
Hairil Anwar \\ Department of Forestry, Faculty of \\ Agriculture \\ University of Mataram \\ Mataram, Indonesia
}

\author{
Kornelia Webliana \\ Department of Forestry, Faculty of \\ Agriculture \\ University of Mataram \\ Mataram, Indonesia
}

\author{
Lale Dini Ardiantari \\ Department of Forestry, Faculty of \\ Agriculture \\ University of Mataram \\ Mataram, Indonesia
}

\author{
Ika Andayani \\ Department of Forestry, Faculty of \\ Agriculture \\ University of Mataram \\ Mataram, Indonesia
}

\begin{abstract}
This study aims to analyze the performance of forest management carried out by FMU of West Rinjani with a focus on the 13 criteria as set out in the instrument criteria and assessment indicators that have been compiled based on PERDA 14 of 2019, the criteria referred to consist of; forest management institutions, forest governance and preparation of management plans, utilization and use of forest areas, forest protection and nature conservation, rehabilitation and reclamation, empowerment, community participation, cooperation, monitoring and evaluation, forestry information systems, guidance and supervision, funding, as well as facilities and infrastructure .. This research was conducted in April-September 2020 located in the West Rinjani FMU area of NTB province, using various data collection instruments such as document studies, interviews, and Focus Group Discussions. The analysis in this assessment is descriptive. The data processing stage consisted of data tabulation and data analysis based on field findings. The results of the study show that the performance of KPH Rinjani Barat is at an average value of 2.64 sfrom the maximum value of 3 . This means that the performance of forest management in the West Rinjani FMU area is classified as high $\mathbf{( 2 . 3 4 - 3 . 0 0})$, This means that the forest management process carried out by KPH Rinjani Barat can fulfill most of the management mandates in PERDA 14 2019.
\end{abstract}

Keywords- Performance, Forest Management Unit, Analysis

\section{INTRODUCTION}

Forest resource management defined as the integration of the organizational structure, authorities and responsibilities, mechanisms and procedures/processes, operational practices, and resources for the implementation of forest resource management. Forest resource management includes all functional aspects of management to develop, achieve and maintain policies and management objectives that are implemented. Forest area management through the Operationalization of FMUs as regulated in Law 41/1999 [1] on forestry and its derivatives PP 62007 [2] jo PP 32008 [3], has put a firm emphasis on the strategic position of FMU institutions in controlling consistency and achievement of implementation site-level forestry development in various regions, including West Nusa Tenggara (NTB), which has 15 FMU units and is spread across 10 districts and cities.

Conceptually, FMUs are built or developed so that they have the ability to carry out forest management based on forest resources, including developing the interests of the parties, developing investments, providing more complete information about natural resources and their problems as a basis for determining management, and implementing the implementation of adjusted laws and regulations with local conditions [4]. In addition Kartodihardjo, et al., (2014) [5] also made an analogy of the existence of FMU organizations and personnel at the site level such as "houses and its occupants" on a "stretch of land". "Houses" are KPH organizations, "its occupants" are FMU organizational personnel, while "land stretches" are state forest areas.

The forest resource management system's application cannot be separated from the influence of policy changes at the national and regional levels [6]. One of these changes was made in response to the implementation of Law Number 23 the Year 2014 [7] concerning Regional Government, which specifically influences the forest resource management system at the regional level. With the 
implementation of this policy, forest resource management affairs, which were originally also the affairs of the regional government at the district/city level, are now becoming the Province's affairs. This absolutely has consequences for the forest management process that is carried out at the site level, including the management system run by the Forest Management Units (FMU). In response to policy changes at the national level, the provincial government of NTB has compiled PERDA No. 14 of 2019 [8] concerning forest management as a basis for strengthening governance at the site level.

The position of West Rinjani FMU which is based on the ecosystem approach at the site level is one of the pioneers in encouraging the process of improving forest governance in the NTB province. With such complex location characteristics, it is ensured that the management process carried out has unique dynamics in accordance with the conditions of each region In the previous period, the assessment of forest management performance by FMU of Rinjani had been carried out by Ichsan (2015) [9] using the FWI 1.0 criteria and indicators with 8 criteria and 22 indicators. Thus, this study takes a position to assess the performance of FMUs based on local characteristics by referring to the Regional Regulation on forest management that has been established previously. This study aims to analyze the performance of forest management carried out by FMU of West Rinjani with a focus on the 13 criteria as stated in the instrument of criteria and assessment indicators that have been compiled based on PERDA 14 of 2019. With the hope, this research is able to become an analytical instrument and a reference source for policy information in an effort to improve FMU-based forest management in the West Rinjani management area.

\section{METHOD}

This research was conducted in April-September 2020 located in the FMU of West Rinjani area of NTB province, using various data collection instruments such as document studies, interviews, and Focus Group Discussion [10];[11]. The analysis in this assessment is descriptive in nature, which aims to collect existing information at the moment, analyze it and interpret the facts or information found [12]; [13]; [14].

The final results of this assessment are presented in the form of an FMU performance index and narrative. The index was calculated using the mean formula, which is to calculate the total value of all data units then divided by the number of data units [ 15 ]. The FMU Development Performance appraisal index was categorized into three classes, namely High, Medium and Low with the following explanations:
TABLE I. CATEGORIZATION OF FMU DEVELOPMENT PERFORMANCE APPRAISAL INDEX

\begin{tabular}{|c|c|c|c|}
\hline $\begin{array}{l}\text { Index } \\
\text { Value }\end{array}$ & & Category & Description \\
\hline $\begin{array}{l}2,34 \\
3,00\end{array}$ & - & High & $\begin{array}{l}\text { The ideal average value obtained from each } \\
\text { quality element, indicator, and criterion. }\end{array}$ \\
\hline $\begin{array}{l}1,67 \\
2,33\end{array}$ & - & Medium & $\begin{array}{l}\text { The medium category average value } \\
\text { obtained from each quality element, } \\
\text { indicator and criterion. }\end{array}$ \\
\hline $\begin{array}{l}1,00 \\
1,66\end{array}$ & - & Low & $\begin{array}{l}\text { The low category average value obtained } \\
\text { from each quality element, indicator and } \\
\text { criterion. }\end{array}$ \\
\hline
\end{tabular}

(Source: FWI 2014)

The index above is processed from the score of each quality element which has a gradation from the highest to the lowest value, with the consideration of each weight in the quality element and indicator is equivalent.

TABLE II. CATEGORIZATION OF FMU DEVELOPMENT PERFORMANCE ASSESSMENT SCORES

\begin{tabular}{ll}
\hline Description & Score \\
\hline $\begin{array}{l}\text { If the field data meets all the elements contained in the } \\
\text { verification table }\end{array}$ & 3 \\
If the field data solely fulfills some of the elements contained & 2 \\
in the verification table & \\
$\begin{array}{l}\text { If the field data does not meet all the elements contained in } \\
\text { the verification table }\end{array}$ & 1 \\
\hline
\end{tabular}

Note: The assessment score is a choice of decisions based on the findings that have been analyzed and verified.

The data processing stage consisted of data tabulation and data analysis based on field findings. The Criteria and Indicators components in this assessment are based on a matrix of criteria and indicators that has been developed previously based on the NTB Regional Regulation No. 14 of 2019 concerning forest management.

\section{RESULT AND DISCUSSION}

Specifically, the instruments used in this study are accorded to the substance of the material contained in PERDA No. 14 of 2019 concerning Forest Management, consisting of 13 criteria, including forest management institutions, forest management and preparation of management plans, utilization and use of forest areas, forest protection and nature conservation, rehabilitation and reclamation, empowerment, community participation, cooperation, monitoring and evaluation, forestry information system, guidance and supervision, funding, and facilities and infrastructure. The results of the general assessment can be seen in Figure 1. Of the 13 assessed criteria, the average of all criteria is in a good range, which means the FMU of West Rinjani is adequate in carrying out forest management tasks and functions at the site level. in detail about the information for each criterion can be seen in Figure 1 and the explanation below: 


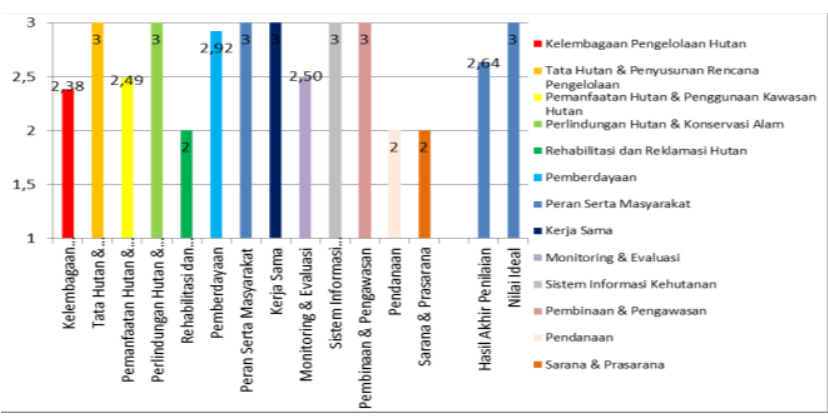

Fig. 1. Figure 1. Matrix of the development performance assessment result of West Rinjani FMU

\section{A. Forest Management Institutions}

The results of the assessment show FMU of West Rinjani, in general, has implemented the operationalization of competency standards referring to Ministerial Regulation No. 42 of 2011 [16] concerning Competency Standards in Forestry Technical Fields at KPHL and KPHP. This can be proven by the existence of an organizational structure consisting of the Head of FMU, Head of Section, Head of Resort, and Group of functional positions in accordance with their respective main duties and functions in implementing forest management. In addition, P.42 of 2011 also mandates that employees who fill structural or functional positions must meet predetermined competency standards. in this case, the Head of West Rinjani FMU himself has met the specified administrative requirements, namely having a minimum formal education level of S1 Forestry and having a minimum rank and class III / b, $\mathrm{KKPH}$ Rinbar also has taken the KKPH competency test and has attended training conducted by the institution of professional certification in the forestry sector.

FMU Resort is the smallest unit in FMU carrying out operational activities and/or technical activities supporting the Service in the field of sustainable forest management in accordance with its function and designation. specifically FMU of West Rinjani has 8 resorts consisting of Sesaot Resort, Jangkok Resort , Meninting Resort, Tanjung Resort, Malimbu Resort, Monggal Resort, Santong Resort, and Senaru Resort. The form of resorts in West Rinjani FMU has been implemented based on article 10 paragraph 2, including regional management units and industrial units. The area management unit can be seen from the utilization of water resources, natural tourism management, and etc. Meanwhile, the industrial unit can be seen with the handicraft industry, wood management industry, and etc.

The area of West Rinjani FMU is $\pm 40,983$ Ha. The availability of human resources in running FMU institutions is severely limited in terms of both quality and quantity. This can be seen from the small number of officers in managing areas in the FMU. Thus, the distribution of forest management personnel owned by FMU of West Rinjani does not quite fulfill the mandate of the Perda with a minimum ratio of 1: $500 \mathrm{Ha}$.

\section{B. Forest Administration and Forest Management Planning}

Related to the implementation of forest administration activities, FMU of West Rinjani has carried out several inventory activities including in 2011 in KH. Pandan Mas (RTK.2) and KH. Mount Rinjani (RTK.1) covering an area of $\pm 5,200 \mathrm{Ha}$, and for 2012 in KH. Mount Rinjani (RTK.1) covering an area of $\pm 7,000$ hectares. The plot area as referred to in Article 13 paragraph 3 is related to the area of the protected forest area of at least $50 \mathrm{Ha}$ and the production area of at least $25 \mathrm{Ha}$. The following is a detailed table of forest layout in West Rinjani FMU.

TABLE III. AREA OF FOREST ADMINISTRATION IN WEST RINJANI FMU

\begin{tabular}{|l|l|l|}
\hline No & Block Division & Area (Ha) \\
\hline 1 & Core & $16.862,84$ \\
\hline 2 & Protected Forest & $11.964,26$ \\
\hline 3 & Permanent Production Forest & $6.984,38$ \\
\hline 4 & Production Forest & $5.171,52$ \\
\hline Total & $40.983,00$ \\
\hline
\end{tabular}
Source: RPHJPd KPHL West Rinjani in 2020

Every FMU should have a forest management plan in the form of a Long Term Management Plan (RPJP) and a Short Term Forest Management Plan (RPHJPd) based on article 14 paragraph 2. FMU of West Rinjani itself has compiled and has an RPHJP of 2014-2023 [17] and it has been legalized. In addition, there is already an RPHJPd document [18] which is updated annually. However, the 2020 West Rinjani FMU RPHJPd document has not yet been approved by the Head of the NTB Provincial Environment and Forestry Service.

\section{Forest Utilization and Forest Area Use}

In the activities of utilizing the West Rinjani FMU, the FMU has made use of NTFPs and environmental services, whereas FMU does not use and collect NTFPs themselves due to the authority of the central government for licensing and administration. The use of NTFPs is carried out by managing eucalyptus oil, honey, coffee, chocolate, and ETC.

Albeit the investment mechanism has not been well documented, in its implementation, FMU of West Rinjani has implemented a profit-sharing system for management with a partnership system. Currently, FMU of West Rinjani is developing a management system in the form of a cooperative that is managed directly by the surrounding community, the profit-sharing system applied in the cooperative is that the community gets $75 \%$ of the profits and FMU of West Rinjani gets $25 \%$. This system has been implemented in the village of Rempek and the cooperative has been established and operating.

\section{Forest Protection and Nature Conservation}

In general, the protection and conservation of nature have been implemented by the FMU of West Rinjani. This can be seen from the forest protection and security efforts that have been carried out by KPHL of West Rinjani including counseling/outreach, formation/coaching of groups associated with rehabilitation activities, participatory forest patrols, functional operations, and joint operations (with the Provincial/District Forestry Service, Mount Rinjani National Park and NTB KSDA Center), and forest fire control. 


\section{E. Rehabilitation and Reclamation}

Rehabilitation and reclamation activities at FMU of West Rinjani are in accordance with the form regulated under Article 40 paragraph 1 in PERDA No. 14 2019, namely RHL is carried out in vegetative and technical civil forms. Based on the 2014-2023 RPHJP, forest rehabilitation is carried out through the following activities: a). Reforestation, b). Greening, c). Maintenance, d). Plant enrichment, or e). Application of vegetative and civil technical soil conservation techniques, on critical and unproductive lands. Forest and land rehabilitation is implemented based on specific biophysical conditions, which prioritizes implementation through a participatory approach in efforts to develop potential and empower communities.

Forest restoration efforts through vegetative activities are carried out by developing plants under-stand on the basis of land-use suitability, this is expected to be able to increase the percentage of land cover and increase forest productivity. Meanwhile, the application of soil conservation techniques in a civil-technical manner can be seen in the 2014-2023 FMU of West Rinjani RPHJP which outlines several activities, among others; manufacture of dams control (DPi), retaining wall (DPn), water reservoirs, and water drainage and waterfall buildings.

\section{F. Empowerment}

The results of the study show that the FMU has implemented community empowerment. Public access rights in general have been contained in the FMU planning document. The guarantee is stated in the form of developing a community partnership system, developing Joint Forest Management Society (PHBM)such as HKm (Community Forest) and HTR (Community Plantation Forest). Specifically in areas that have obtained IUPHHKM (license for utilization of timber in Social Forestry)and certain areas as well as recognition of the rights of customary communities through joint decisions between KKPH and representatives of customary institutions. In addition, FMU has carried out socialization, training, forming groups, consultations, and providing assistance with facilities and infrastructure in the management of forest products.

On the other hand, FMU of West Rinjani has also developed efforts to develop community products that are focused on the processing industry around FMU of West Rinjani which is a household scale industry in the form of NTFPs such as jackfruit, belinjo, and palm sugar as well as non-NTFP processing such as coffee and banana. The byproducts are dodol, chips, chips, palm sugar, sugar ant and ground coffee. Increasing public awareness about forest management will be elaborated through stages (a). Formation of forest farmer groups (KTH), $200 \mathrm{KTH}(\mathrm{b}) .10$ activities of forest farmer group development, (c). Development of productive plants under 9,000 hectares of stands, (d) assistance of TTG equipment, and 36 packages of processed Non-timber forest products (NTFP) products, (e). Development of 9 units of beekeeping business groups, (f). 36 cooperatives of forest farmer groups, (g). Facilitation of forestry partnership credit 60 activities.

\section{G. Community Participation}

Based on the results of interviews, the community was fully involved in forest management, benefiting in the form of forest products such as coffee, honey, sugar palm, and etc. In addition, the utilization of natural tourist attractions management can be one of the economic resources that the surrounding communities perceived directly. This can be seen based on the results of tracing the involvement of the community in forest management and the community obtaining the benefits resulting from the forest area listed in the 2020 short term forest management planning (RPHJPd) document.

\section{H. Monitoring and Evaluation}

The implementation of MONEV activities on forest management at the FMU of West Rinjani Hall refers to article 49 paragraph 3 which is carried out together with non-governmental organizations, academics, and/or communities around the forest area who have been involved in the implementation of monitoring and evaluation. This can be seen in the description of the evaluation activities and the implementation team for evaluating activities carried out by the West Rinjani FMU Hall in the 2020 RPHJPd document. Non-governmental organizations taking a part in the evaluation team are $\mathrm{KTH}$, customary institutions, and NGOs, while academics who are included are academics from University of Mataram.

This monitoring and evaluation activity based on article 50 paragraph 1 is executed at least once a year and has been carried out by the FMU of West Rinjani in accordance with the stipulated mandate. In 2020 monitoring and evaluation will be executed online (in-network) given the state of the coronavirus which remains spreading.

\section{Forestry Information System}

Presently, West Nusa Tenggara's forestry information system management activities can be accessed through the website www.dislhk.ntbprov.go.id. In general, the information system presented covers all aspects based on Article 52 covering the planning, utilization, protection, and management of forest resources. Apart from public information, the public is also provided online services such as requests for information, complaint cases, and officials' complaints.

On the website of the LHK (Environment and Forestry) office, there is no specific information related to FMU of West Rinjani. The available information is general information about the condition of forests and forestry in NTB. Specific data presentation related to FMU of West Rinjani is solely accessed through the page www.kph.menlhk.go.id. However, no information has been found related to updating the data on the website.

\section{J. Guidance and Supervision}

The assessment result shows that development activities such as planning, utilization, protection, and management of forest resources as well as monitoring and evaluation have been carried out by FMU of West Rinjani. The planned forest utilization is in the form of non-timber forest products and environmental services for nature tourism. Utilization 
of natural tourism which is a priority for FMU of West Rinjani, including:

- Collection and management of eucalyptus leaves

- Harvesting and managing patchouli leaves

- $\quad$ Processing wood pellets

- Cultivation of trigona

- Management of tourist areas such as Aiknyet, Sesaot, Pusuk, Tiu Tiding and Ranget

FMU of West Rinjani has executed forest management coaching activities in accordance with the scope of the regulations stipulated in the Perda. This can be seen from the activity report in August 2020, FMU of West Rinjani has carried out KUPS activities for the cultivation of Trigona honey bees in the Bintang Sari group consultation activities on the implementation of RHL activities in the KTH Lestari Alam area, Mekar Sari Village and KTH Hijau Makmur, Gelanggar Village which was carried out jointly with PT Aman Mineral, as well as Monev team visit activities related to FIP at HKm Santong.

\section{K. Funding}

Funding for the implementation of forest management based on article 57 paragraph 1 derives from the APBN, APBD, and other legal and non-binding sources. In which, the budget allocation obtained is used for the protection and conservation of natural resources, rehabilitation, and social forestry, as well as forest management and forestry investment. Apart from the budget obtained from the APBN and APBD, there are other budgets obtained from other sources, such as the World Bank and PT.AMNT. However, the budgets obtained are unable to meet the operational needs of the West Rinjani KPH Hall as a whole.

\section{Facilities and infrastructure}

In accordance with the results of the assessment of the facilities and infrastructure available at FMU of West Rinjani based on the Dirjen PDASHL 2020 circular letter, some of them have been fulfilled, such as office buildings, resort buildings, 2-wheeled vehicles, 4-wheeled vehicles, furniture, communication equipment, software, computer hardware, and also survey equipment. However, some of the facilities and infrastructure already owned are in poor condition. Apart from that, several things are needed to be equipped such as fire extinguishing equipment, because FMU of West Rinjani does not have fire extinguishing equipment for both the office and the field.

\section{Analysis and synthesis}

Conceptually, the procedures and functionalization of FMUs have been regulated in Government Regulation No. 06 of 2007 and are translated again into several forestry ministerial regulations such as PERMENHUT No P.6 2009 concerning Establishment of FMU Areas, PERMENHUT No P.41 2011 [19] concerning Facilitation Standards for Facilities and Infrastructure of Model Protected Forest Management Units and Model Production Forest Management Units, PERMENHUT N0 422011 concerning
Competency Standards in Forestry Technical Fields in Protected Forest Management Units and Production Forest Management Units. Based on the directions in these regulations, it is generally illustrated that the formation and functionalization of FMUs is a process of institutional shift that brings fundamental changes to the way of thinking, value systems, and culture of Indonesian forest management [20].The FMU's role will shift the fulcrum of forest resource management from forest administrator to forest manager, and increase transparency and accountability of forest governance. Thus, in order to ensure the fulfillment of the objectives of an effective FMU development, a policy formulation is needed that is able to properly describe the situation and problems arising from the implementation of forest management at the site level [21].

Institutional performance is defined as the ability of an institution to use its resources efficiently and produce output that is in accordance with its objectives and relevant to user needs [22].There are two items to assess institutional performance, namely the product itself in the form of a service or material, and the management factors that make the product possible [23]. According to Mackay (1998) [24] there are four dimensions to studying an institution (institutional assessment), namely:

First, the external environment. The social environment in which an institution lives is an influencing factor that can be a driving force and at the same time limiting how far an institution operates. The environment referred to administrative and external policies environment, sociocultural environment, technological environment, economic environment, various interest groups (stakeholders), infrastructure, as well as policies on the management of natural resources. All components of the environment need to be studied and be analyzed in the form of their influence on the studied institutions. Some have a more direct and stronger influence, some don't. The implications of the formulated policies can be addressed to the environment if it is concluded that it has become an inhibiting factor for the operation of an institution. Second, institutional motivation. The institution is seen as a unit of study that has a soul of its own. There are four aspects that can be studied to determine institutional motivation, namely institutional history, the mission it carries, the culture that guides the attitude and behavior of its members, and the incentive schemes. A social fact is a historical fact. The history of the journey of other institutional aspects. Third, institutional capacity. In this section, it is studied how the institutional ability to achieve its own goals. This capability is measured from five aspects, namely: strategic leadership, program planning, management and exect

allocation, and relations with outsiders, namely towards clients, partners, government policymakers, and external donors. Fourth, institutional performance. There are three main things that must be considered, namely the effectiveness of the institution in achieving its goals, the efficient use of resources, and the sustainability of the institution in interacting with interest groups outside it. It is impressive that economic calculation is the principle against which it backgrounds. To measure effectiveness and efficiency, a simple quantitative analysis can be used, for example, by making a ratio between the supposed and actual gains achieved, as well as the ratio of costs to productivity. 


\section{CONCLUSION}

In general, the performance assessment result of West Rinjani FMU shows an average value of 2.64 from the maximum value of 3 . This includes that the performance of forest management in the West Rinjani FMU area is high (2.34-3.00). This means that the forest management process executed by the FMU of West Rinjani can fulfill most of the management mandates as outlined in PERDA 142019. Nevertheless, there are still several aspects is needed to be recommended in the framework of strengthening the operationalization of FMUs at the site level, including: Forest planning aspects in the form of confirming the unfinished boundaries between blocks, administrative aspects include providing SOPs for data services, law enforcement, decision making, archiving, and documentation, institutional aspects in the form of guaranteed budget operations and organizational structures that meet applicable regulatory standards, strengthening Human Resources in the form of Capacity, Number, and Competency Enhancement, strengthening information systems in the form of inputs, processes, outputs, updating data and services, and strengthening investment as an independent FMU (SOP, a structure to support investment towards being independent).

\section{REFERENCES}

[1] Government of the Republic of Indonesia. 1999. Laws of the Republic of Indonesia No. 41 of 1999 on Forestry. Lembaran Negara RI Tahun 1999 No. 167. Jakarta

[2] Government Regulation No. 6/2007 Concerning Forest Structuring and the Making of Forest Management Plans, and Utilization of Forests. Jakarta

[3] Government Regulation No. 3/2008 on the Amendment to Government Regulation No. 6/2007 on Forest Arrangement and Formulation of Forest Management Plan and Utilization of Forest. Jakarta

[4] Kartodihardjo H, Nugroho B, Putro HR. 2011. Forest Management Unit Development (FMU): Concept, Legislation and Implementation (Pembangunan Kesatuan Pengelolaan Hutan (KPH): Konsep, Peraturan Perundangan dan Implementasi).Jakarta: Kementerian Kehutanan RI.

[5] Kartodihardjo H, Suwarno E. 2014. Mainstreaming of Forest Management Units (FMU) in Forestry Licensing Policy and Implementation (Pengarusutamaan Kesatuan Pengelolaan Hutan $(\mathrm{KPH})$ dalam Kebijakan dan Pelaksanaan Perizinan Kehutanan).Jakarta: Direktorat Wilayah Pengelolaan dan Penyiapan Areal Pemanfaatan Kawasan Hutan Direktorat Jenderal Planologi Kehutanan.

[6] Ichsan, A. C., Aji, I. M. L., Webliana, K., \& Sari, D. P. (2019, May). The Analysis of Institutional Performance of The Village Conservation Model in Gunung Rinjani National Park. In IOP Conference Series: Earth and Environmental Science (Vol. 270, No. 1, p. 012019). IOP Publishing.

[7] Pemerintah Republik Indonesia. 2014. Undang-Undang Nomor 23 Tahun 2014 tentang Pemerintahan Daerah. Republik Indonesia. Jakarta.

Peraturan Daerah Nusa Tenggara Barat No 14 Tahun 2019. Tentang Pengelolaan Hutan. Mataram

[9] Ichsan, A. C., \& Febryano, I. G. (2015). Assessment of the development performance of West Rinjani Protected Forest Management Unit, West Nusa Tenggara Province (Penilaian kinerja pembangunan Kesatuan Pengelolaan Hutan Lindung Rinjani Barat, Provinsi Nusa Tenggara Barat). Jurnal Hutan Tropika, 3(2), 192-198.

[10] Mulyana D. 2006. Qualitative Research Methods (Metode Penelitian Kualitatif). Bandung (ID): PT Remaja Rosdakarya.

[11] Irawan P. 2006. Qualitative and Quantitative Research For Social Sciences (Penelitian Kualitatif dan Kuantitatif Untuk Ilmu Ilmu Sosial). DIA FISIP UI: Jakarta

[12] Narbuko Cholid. 2002. Research Methodology (Metodologi Penelitian). Jakarta. Bumi Aksara.

[13] Bungin B. 2003. Qualitative Research Data Analysis (Analisis Data Penelitian Kualitatif). Jakarta (ID): Radja Grafindo Persada.

[14] Ichsan, A. C. (2018). Performance of the Development of Sungai Wain Protected Forest Management Unit and the Manggar Watershed in East Kalimantan Province (Kinerja Pembangunan Kesatuan Pengelolaan Hutan Lindung Sungai Wain dan
DAS Manggar di Provinsi Kalimantan Timur). Jurnal Belantara, 1(1), 01-09.

[15] [FWI $\quad$ Forest Watch Indonesia. 2014. Guidelines for FMU development performance appraisal using FWI 1.0 Criteria and Indicators (Panduan penilaian kinerja pembangunan KPH dengan Menggunakan Kriteria dan Indikator FWI 1.0.) Bogor: Forest Watch Indonesia.

[16] Peraturan menteri Kehutanan No 42 tahun 2011. Tentang Standar kompetensi bidang teknis kehutanan pada kesatuan pengelolaan hutan lindung dan kesatuan pengelolaan hutan produksi. Jakarta

[17] Kesatuan Pengeloaan Hutan Rinjani Barat , 2020. Dokumen Rencana pengelolaan Hutan Jangka Panjang 2014 2023. Dinas Lingkungan Hidup Kehutanan Provinsi Nusa Tenggara. Mataram

[18] Kesatuan Pengeloaan Hutan Rinjani Barat , 2020. Dokumen Rencana pengelolaan Hutan Jangka Pendek 2020. Dinas Lingkungan Hidup Kehutanan Provinsi Nusa Tenggara. Mataram

[19] Peraturan menteri Kehutanan No 41 tahun 2020. Tentang standar fasilitasi sarana dan prasarana kesatuan pengelolaan hutan lindung model dan kesatuan pengelolaan hutan produksi model. Jakarta

[20] Suwarno, E. 2014. Institutional Analysis of FMU Operationalization Process: Case Study of KPHP Tasik Besar Serkap in Riau Province (Analisis Kelembagaan Proses Operasionalisasi KPH: Studi Kasus KPHP Tasik Besar Serkap di Provinsi Riau).Disertasi [Tidak diterbitkan]. Bogor: Sekolah Pascasarjana IPB.

[21] [GFI] Governance Forest Initiative Indonesia. 2013. Potret Pelaksanaan Tata Kelola Hutan: Sebuah Studi Mendalam Di Provinsi Kalimantan Tengah dan Nusa Tenggara Barat.Bogor: Forest Watch Indonesia

[22] Peterson W, Gijsbers G, Wilks M. 2003. An Organizational Performance Assessment System for Agricultural Research Organizations: Concepts, Methods, and Procerures. ISNAR, The Hague, Netherland.

[23] Sahyuti. 2004. Model of Institutional Support for Agricultural Development in Lebak Land (Model Kelembagaan Penunjang Pengembangan Pertanian di Lahan Lebak) [Paper] Workshop Nasional Pengembangan Lahan Rawa Lebak, Balittra tanggal 11-12 Oktober 2004 di Banjarbaru dan Kandangan, Kalimantan Selatan.

[24] Mackay R, Horton D. 1998. Assessment of the organizational impacts of the PM\&E project: Assessment and methods. Paper presented at the assessment of organizational impacts of ISNAR's PM\&E project workshop held at the CGIAR secretariat, Washington D.C (US): August 4-6, 1998. The Hague: International Service for National Agricultural Research (ISNAR). 